\title{
THE LIFE AND WORKS OF SIR WILLIAM JAMES ERASMUS WILSON
}

\author{
I $809-84^{*}$ \\ by \\ R. M. HADLEY
}

Hz will be remembered amongst the greatest dermatologists of his time as a man of singularly benevolent and philanthropic disposition who gave largely to many purposes in connection with his own profession. 1

Thus remains this tribute to Sir Erasmus Wilson spoken by an equally eminent member of the same profession, Sir James Paget. In the space of just over sixty of the most exciting years in medical history, Erasmus Wilson had gained this reputation for himself, unaided by birthright or favour and using his skill and diligence. To rise from being the son of a simple hard working fleet surgeon to become the founder of modern dermatology, an acknowledged expert on Egyptology, and be classed among the greatest medical philanthropists was no mean achievement even by present day standards.

\section{Early Life}

Erasmus Wilson was born on 25 November 1809 at the house of his maternal grandfather, Erasmus Brandsdorph, a Norwegian, in the Marylebone High Street. ${ }^{2}$ His father was by profession a fleet surgeon in the Royal Navy and by birth a native of Huntly in Aberdeenshire. His mother, partly Norwegian in ancestry, was a talented amateur artist, a gift which, handed on to her son, was to stand him in good stead in later life. His early childhood years were no doubt spent at this house in London though there is no definite evidence of this and it appears that his father was frequently abroad serving in Nelson's Mediterranean fleet during the long French war. At the cessation of hostilities William Wilson moved to Dartford in Kent and set up practice at Greenhithe. One author ${ }^{3}$ attributes this move to the presence nearby of a great friend and pupil from Aberdeen, a Dr. William Thompson, who was practising at Crayford, a small village to the East of Dartford.

Beginning his general education at Dartford Grammar School, the young Erasmus was later tutored privately in the arts by the Reverend George Renouard whose parish of Swanscombe was close by. The Reverend Renouard was a famous man in the district, being well known for his literary and teaching abilities. The parish records still existing show his rectorship of the little tenth century church as extending from 1818 to 1867.4 This private education was to be repaid by Erasmus in later life in the form of considerable benefactions to the church.

* The Wix Prize Essay, St. Bartholomew's Hospital, 1958. 


\section{R. M. Hadley}

It soon became apparent that general education was not to assume very large proportions in Erasmus' life, and his destined profession was decided by the age of sixteen when his father sent him to be resident pupil of George Langstaff ${ }^{5}$ at the Cripplegate Dispensary, then situated at 13 Fore Street, in the City of London. ${ }^{6}$ He went therefore to London in 1825 already partly equipped with a knowledge of the methods of medicine and surgery, for his father had by this time assumed the post of Medical Officer of Health for the Dartford district ${ }^{7}$ and Erasmus had been made to assist in his father's duties, working at the Workhouse Infirmary in Dartford. ${ }^{8}$

\section{As a Medical Student}

The medical world in which Erasmus found himself, as a very young student by twentieth-century standards, was in a state of turmoil and reformation. To us it would seem unusual that students should become house pupils and attend at the small dispensaries and schools of medicine, but in $18 \mathrm{I}$, only fourteen years previous to Wilson's residence, Dr. Hervey, Registrar of the Gollege of Physicians, observed

that there was no need of medical schools as the metropolis abounded with noble hospitals and that medical education was better promoted by numerous private schools as at present arranged than it would be by any national establishments..$^{\circ}$

The only hospital medical schools in existence at the beginning of the century were St. Bartholomew's, The Borough Hospitals and The London. By the 1820's the number of well known small schools was considerable and included William Hunter's original establishment in Great Windmill Street, Skey's School in Aldersgate Street and those in Great Marlborough Street, Blenheim Street and Webb Street, this last being a new establishment formed at the back of $\mathrm{Mr}$. Guy's hospital. The success of these schools was due to the fact that they taught anatomy all the year round ${ }^{10}$ in spite of the difficulty in preserving bodies during the summer period (May-November). With the advent of so many new schools the increase in the number of students became for the anatomists a major problem, for the supply of bodies had to keep pace with an increase of approximately one thousand new dissectors per year. ${ }^{11}$ The way of producing these extra subjects is now common knowledge, spiced as it is with the feats of Burke and Hare in Edinburgh in 1827. As to the students themselves Dickens' famous description of Bob Sawyer and Ben Allen whitewashes over the cynicism and foul mouthed indecency for which they and not a few of their teachers were renowned. Henry Acland in a description of the students at St. George's wrote:

Everything wears the air of low men, of low habits such as $I$ have never hitherto come in contact with. ${ }^{12}$

This was a remark made after considerable travel experience in men-of-war and ships of the line.

Into this company went Erasmus Wilson to study anatomy and physiology 


\section{The Life and Works of Sir William James Erasmus Wilson}

with medicine and surgery, pharmacy and midwifery, for the Licentiate of the Apothecaries Hall, an examination which had been made compulsory by law on 12 July 18 I 5 . The financial position of these students was on many occasions quite acute and the problems besetting William Wilson can easily be appreciated as he had to provide at least $£ 80$ per annum for the living of his son as well as a not inconsiderable sum to members of the hospital staff to enable Erasmus to get even beyond the basic stages. Records have it that it cost in all $£ \mathrm{I}, 000$ to become a physician, $£ 120$ to become a surgeon and to qualify as an apothecary $£ 50$. The enormity of these sums is more easily realized when the cost of butter at $6 d$. per pound, eggs at I $d$. each and beer at $5 d$. per pint is examined to give a measure of the cost of living.

Wilson's residence with George Langstaff cannot have been long, for in 1828 and again in 1830 he attended lectures in Paris given by Aurier and Geoffrey St. Hilaire. As France was, at that period, the undisputed leader in medicine it was not unnatural that a student should study under the eyes of the best teachers and avail himself of the French style of teaching with its emphasis on clinical medicine.

Roget, in a published lecture given at the Aldersgate School of Medicine said of the French teaching:

The analogies of form discernible in corresponding organs throughout the very extensive series of tribes has been lately traced and developed with extraordinary industry by the modern naturalists of the French school: especially by Geoffrey St. Hilaire, Cuvier, Savigny and Blainville. ${ }^{16}$

It is of some importance to note that France had made lawful the cheap and plentiful supply of cadavers. ${ }^{13}$ Many persons went to Paris which provided amongst its delights the best way to learn practical medicine quickly and cheaply. ${ }^{14}$ In between his visits to Paris and whilst still attending the Cripplegate School Erasmus Wilson also attended lectures given by John Abernethy in his new lecture theatre, a building apparently of some size: at its inauguration on I October I822 his first lecture had 'an interested audience of some four hundred and six persons' ${ }^{15}$ It is easy to imagine Wilson listening to the

trim little man dressed in black silk stockings and not infrequently wearing a top coat with a little tippit cap, his hair powdered and his bright little twinkling eyes looking in a rather droll manner around. ${ }^{17}$

The personal contacts which Erasmus Wilson made during his student days were of the utmost value in later life and they included working with Lawrence, Jones Quain and Francis Kiernan. His ability as a dissector and capability as an artist soon made themselves apparent and in $183^{\circ}$ he won prizes in surgery and midwifery at the Aldersgate School of Medicine run by Skey. His student career ended on the evening of his twenty-first birthday when, as was the practice of the day, he sat for and passed the Licentiate Examination of the Society of Apothecaries. One author relates the tale of the value that botanical education 


\section{R. M. Hadley}

had for Erasmus as evidenced in the examination when the examiners produced a tray of freshly gathered plants for him to identify. This it seems he must have been able to do with ease. ${ }^{18}$ It seems also that he must have continued with his education at the Aldersgate School, for exactly one year later, on 25 November 1831, he became a member of the Royal College of Surgeons of England.

An improbable tale is narrated by an early biographer concerning his examination:

'What are the muscles of the external ear?' was a question from Sir William Blizard, which might have been a poser for many a student; but the diagrams exhibited in the theatre of St. Bartholomew's and preserved in his notebook enabled Wilson not only to answer it correctly, but to produce so good an impression on the examiners that the rest of the examination passed off without difficulty. ${ }^{19}$

From this time onwards he never looked back in spite of the lean years soon after his marriage. His acquaintance with Jones Quain at Aldersgate led to his first appointment.

\section{Anatomy Demonstrator}

A young man of twenty-two with the degree of Membership of the Royal College of Surgeons, and a remarkable ability in anatomical dissection and in drawing, was not going to devote his life at that early age to the competitions of general practice. Against him in this highly competitive field were the elderly rich and well established gentlemen with wide reputations in the cure of the all too common ailments of the period. Wilson was too shrewd a person to hasten his own obscurity by attempting the impossible. Thus when Jones Quain offered him a post at the newly formed University College in Gower Street he readily accepted it. His selection by Jones must have been due to his previous relationship with the great anatomist at Aldersgate and the great skill and promise he showed there earmarked him in Jones Quain's mind as the right person to assist his brother Richard and himself as they began in the establishment of the anatomy school.

It was not a straightforward position that Erasmus Wilson accepted; constantly surrounding him was the bitter argument amongst the Council and professors of the University beginning with the resignation and removal from the Surgery Department of Bell, who had held the chairs of clinical surgery, surgery and physiology concurrently since the foundation of the school in 1828 . The whole affair began when Pattison was given the post of Anatomist and then asked to fill that of Morbid Anatomist as well, leaving Bell to fill the remaining three positions as best he could. In May 1830 Bell threatened resignation unless the medical school were remodelled ${ }^{20}$ and in September of that year went so far as to give up the chair of surgery and was finally asked for his formal resignation by the Warden and Council. This request he responded to in November by refusing to complete the course of lectures. ${ }^{21}$ The Anatomist Pattison was then given the surgical position and his enemy Bennett and he were made adjunct professor anatomy, the fields of work to be covered by each being accurately 


\section{The Life and Works of Sir William James Erasmus Wilson}

delimited in a council memorandum. In the course of the following session, however, Bennett died and Pattison was dismissed for reasons unknown. So it was that in August 1831 Jones Quain was appointed Professor of Anatomy, taking on the work done by Bennett, and Jones' brother Richard was given the position of Demonstrator on the express condition of the independence of the Professor. ${ }^{22}$ Erasmus Wilson was taken on by Jones Quain as assistant to Richard and remained there until Jones was succeeded in 1836 by Sharpey, and Richard became Professor of Practical Anatomy.

The position regarding the supply of subjects for dissection was still acute and this change in professors coincided with the Burke and Hare murders-a coincidence which drew a scurrilous attack from the Fohn Bull newspaper and the following amusing rhyme from De Morgan:

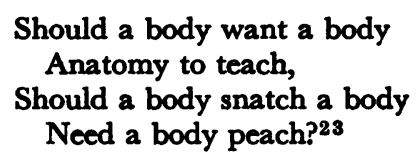

The number of students over which Erasmus had charge, as assistant, was rapidly increasing, from 252 in $1831-2$ to 390 in $1834-5$. These young men gained their clinical knowledge from the dispensary established in September 1828 in George St., Euston Square. As the Quain brothers' assistant it was probable that Wilson also attended this dispensary, for in its foundation it was laid down that 'It should be attended by the professors of anatomy and operative surgery as surgeons.' The continual pressure on space caused by the increasing numbers of students stimulated the Governors of the Medical School to the building of a new hospital 'on land west of Gower Street' and with the view to increasing funds by the large numbers of students such a hospital would be able to accept plans went ahead. These culminated in the laying of the foundation stone in 1833, the building being finished and opened to the public on I November 1834 .

Erasmus remained, as has been stated, at University College until Jones Quain resigned his position there in 1836 . During his five years' residence his tasks lay chiefly in the supervision of students during their periods of dissection and the preparation of specimens and drawings for Jones. (His evenings were devoted to the tuition of students for the Apothecaries Hall and Royal College of Surgeons examinations.) Did he perhaps still have the nickname amongst his pupils which his compatriots had ascribed to him in Paris, namely, 'Le piocheur'? If he did the fact is not recorded. The results of his work appeared several years later in 1837 when he assisted Jones Quain in the production of the latter's volume of plates, 'The Vessels of the Human Body'. A year later, in 1838 , John Churchill produced Wilson's first original work Practical and Surgical Anatomy. (A detailed description of these and his subsequent works is to be found at the end of this essay.)

In the Spring of 1834 he went to Holland, ${ }^{24}$ the delights of foreign travel again 


\section{R. M. Hadley}

attracting him. The purposes of this journey were to visit hospitals and medical museums and, with the aspects of goitre uppermost in his mind, he travelled southwards, spending the summer in Heidelberg and returning through the goitrous areas of Switzerland and Italy during the early autumn. On his return home he directed and supervised the illustrating of Practical or Operative Surgery by Robert Liston who was then surgeon to the North London Hospital.

When Jones Quain resigned his post at University College in 1836 , Wilson, on his own initiative, decided to establish a school of anatomy similar to the many others then flourishing. In this venture he enlisted the help of Marshall Hall, John Dalrymple and others and it became known as Sydenham College after Thomas Sydenham, the celebrated English physician of the seventeenth century. ${ }^{25}$ The location of the college was 22 Sussex Street, Bedford Square, with Wilson for a time living in the same building. This educational venture, launched on I October, did not last long and a letter appeared in the Lancet, I5 January $1837{ }^{26}$ giving his address as 55 Upper Charlotte Street, Fitzroy Square. Plarr's ${ }^{27}$ evidence of the short-lived nature of Sydenham College corroborates its transitory existence.

In 1840 Wilson was appointed lecturer in anatomy and physiology at the Middlesex Hospital. For the three years previously he had devoted his time to writing and general practice and from his able pen came, as mentioned, Practical and Surgical Anatomy and the two anatomical works in collaboration with Quain and Liston. He also devoted much of his time to the new subject of skin diseases. Two articles on this subject appeared in the Lancet of $1839^{28}$ and the course of lectures in 1840.29 This latter was the nucleus of the work by which he is best known, namely, Diseases of the Skin - a practical and theoretical treatise.

During Erasmus' period at University College, William Wilson had retired from the navy and set up a private mental asylum at Deham in Buckinghamshire. ${ }^{30}$ Here the elder Wilson was visited frequently by his great friend Thomas Wakley, founder and editor of the Lancet, and here also Erasmus became acquainted personally with Wakley. The editor of the Lancet was a far-seeing man, advising Erasmus to make himself so well acquainted with diseases of the skin that 'when he entered a room the company would begin to scratch themselves'. ${ }^{31} \mathrm{He}$ could have had no idea that this advice would lead to success of such magnitude that it reached over $£ 200,000$. He also suggested that Wilson should become sub-editor of the Lancet, a post which the latter held for four years until the pressure of work from a rapidly expanding private practice forced him to relinquish it. Thus suddenly in $184^{\circ}$ at the age of thirty-one Erasmus Wilson found himself sub-editor, Gonsultant Surgeon to the Marylebone Infirmary, ${ }^{32}$ Lecturer on Anatomy and Physiology and a rising young man in that new branch of medical science, dermatology.

\section{The Middlesex Hospital and the Marylebone Infirmary}

In spite of what must have been a very full life at the Middlesex Hospital Wilson found time to produce his Diseases of the Skin, The Anatomists Vade Mecum-a System of Human Anatomy, and A History of the Middlesex Hospital 


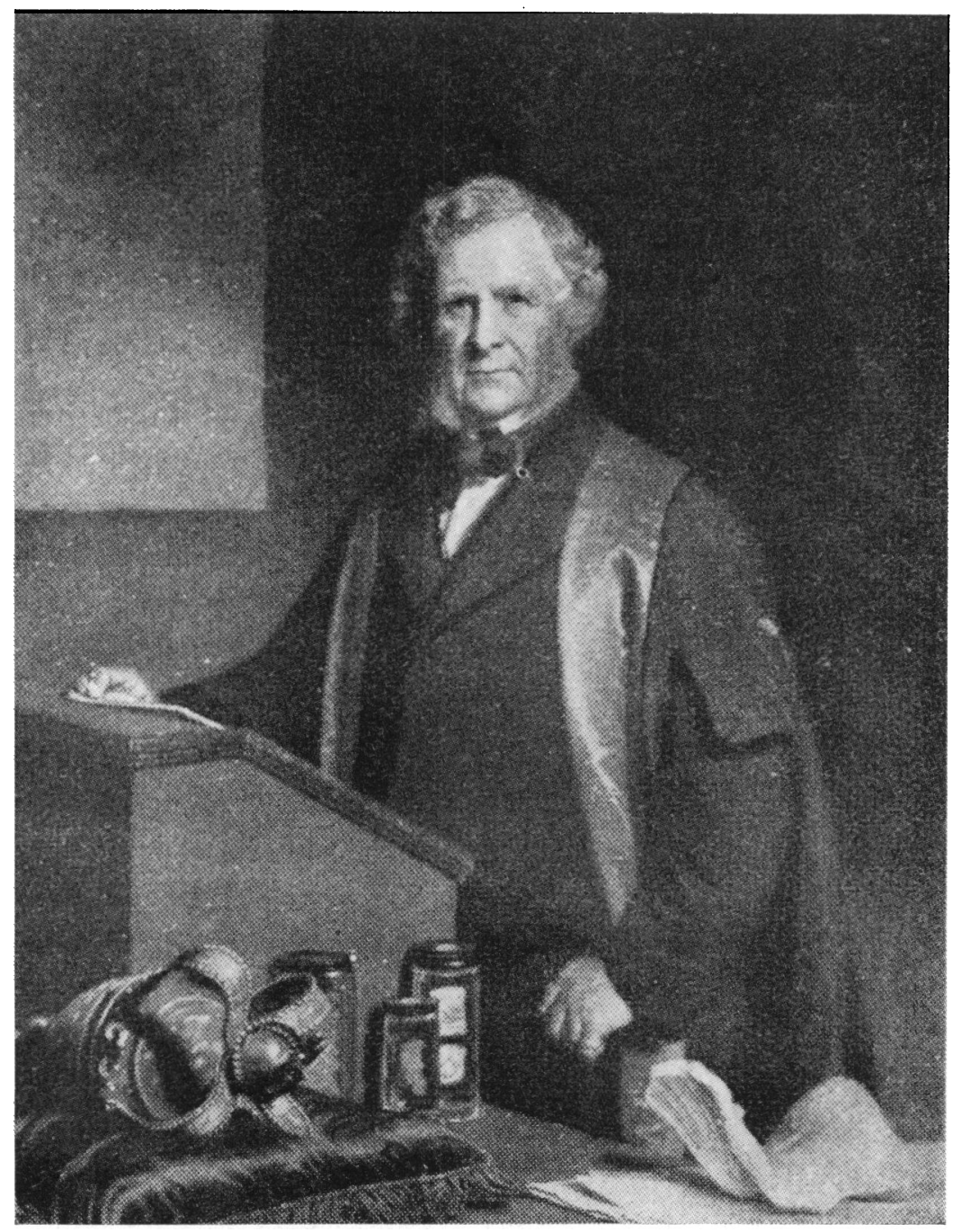

Fig. I

SIR ERASMUS WILSON (1809-1884)

From the portrait by Stephen Pearce in the possession of the Medical Society of London 


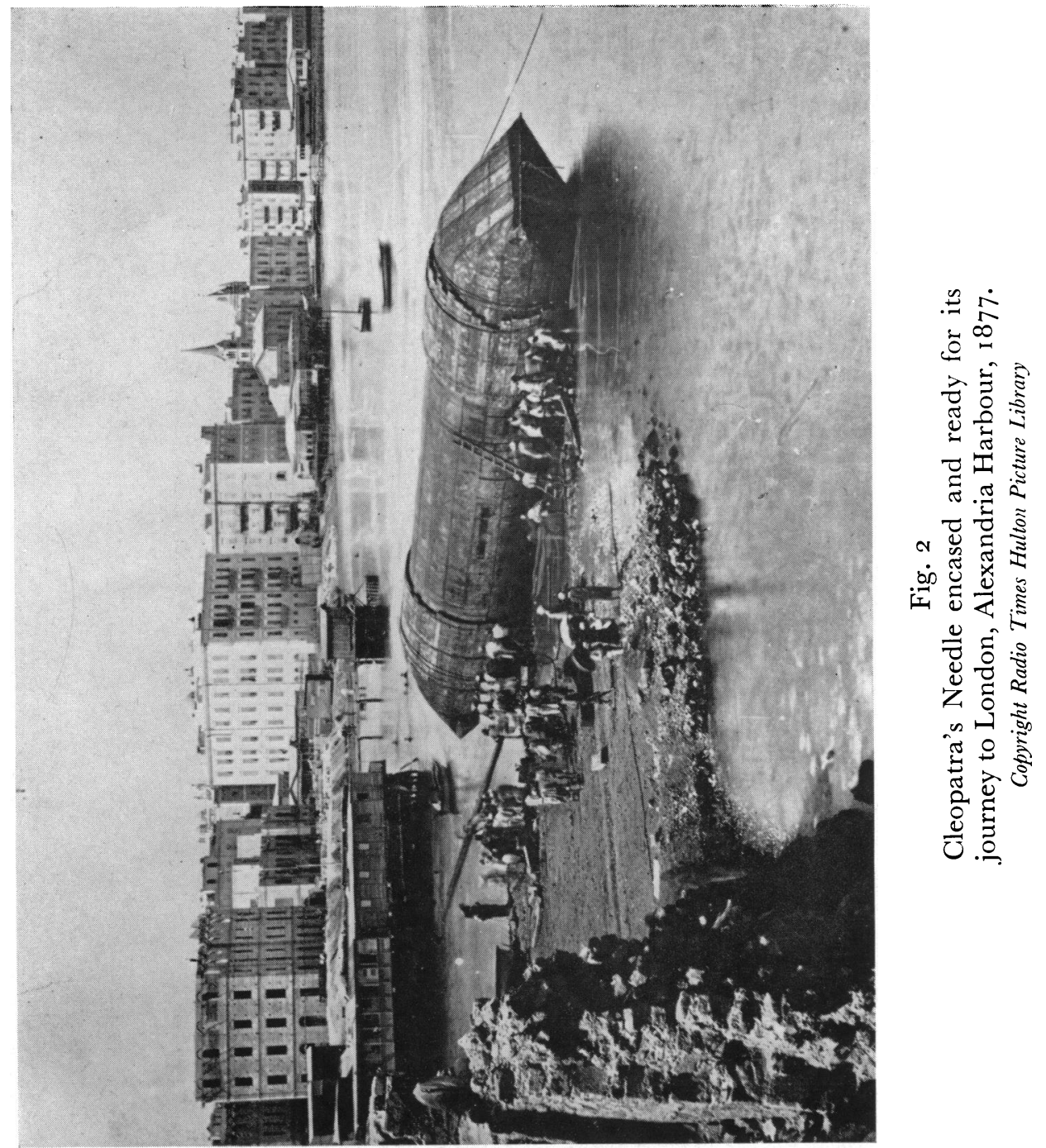




\section{The Life and Works of. Sir William James Erasmus Wilson}

during the first hundred years of its Existence. This latter work was not published until I 845 although it was written during the early 1840 's.

Apart from lecturing and demonstrating it seemed at this time that Wilson's career was destined for surgery. His reputation in this field was considerable; he held the consultant post at the Marylebone Infirmary ${ }^{38}$ (one reputable author ${ }^{34}$ suggests this may have been the St. Pancras Infirmary but he seems to stand alone in his opinion). The Marylebone Infirmary, located in New Road, not far from the Middlesex, was a hospital founded on 16 November $1785:^{35}$

For administering advice and medicines for the relief of the sick and lame poor and pregnant women of the parishes of St. George, Hanover Square, St. Mary-le-Bone, St. Anne Soho, St. Martin, St. Giles and St. Pancras (could this have been the source of Plarr's error?) and places adjacent; at the dispensary or at their habitations.

It received funds from medical practitioners and influential persons by means of an arrangement that:

Subscribers of 30 guineas are Governors for life and are entitled to recommend 30-35 medical or surgical patients annually. The privileges of subscribers are extended in a proportionate ratio for larger sums, provided they be given at one and the same time.

The London Medical Directory for 1854 describes the Infirmary as being under the direction of Dr. Mayo, and containing $33^{\circ}$ beds, receiving 222 out-patients daily, besides having an additional 400 beds in the adjacent workhouse. As the staff was composed of one physician, one surgeon and an apothecary it is easy to understand how busy Wilson must have been in performing this duty alone.

Of his capabilities as a surgeon a writer states: ${ }^{36}$

He was equipped with a steady hand, calm nerve, and a power of acquiring moral ascendancy over his patients. He had that rare quality in the accident ward-that of advising against amputation unless every hope of saving a limb was gone. He often used to account of his youthful impressions of a battle officer who refused to have. his leg cut off and recovered notwithstanding against all advice that he must die or loose his limb.

It must be remembered too that he began to practise when surgery was somewhat crude, especially so in hospitals. The use of anaesthetics did not begin until Liston's first experimental operation under chloroform at Wilson's old hospital, University College, in the early autumn of $184^{6.37}$ Even the carbolic spray and the ideas of antisepsis and wound healing by first intention were 'newfangled' and not to be considered seriously.

\section{Marriage and Honorary Degrees}

In the summer of $184_{1}$ Erasmus found time to devote himself to 'affaires de cœur' rather than medicine and these resulted in his marriage to Miss Doherty, ${ }^{38}$ the only daughter of Mr. James Doherty - a well known figure in the world of the hansom cab. Unfortunately the marriage was to be childless and his wife eventually succeeded him by two years. 


\section{R. M. Hadley}

Two years later and following on the publication of Diseases of the Skin he was elected Fellow of the Royal College of Surgeons and is classed as one of the original one hundred and forty-nine fellows. This election was primarily due to his contribution to the College of a paper on a newly discovered human skin parasite, the Entozoon folliculorum. For this, his first public honour, he must have been extremely grateful for it marked public and official recognition of his specialization in the dermatological field. Wakley in managing to persuade Wilson to overcome his fear of sinking under the dreaded name of quack must also have been satisfied by this College decision. Wilson acknowledged his degree with the following letter: ${ }^{80}$

To the President of the Royal College of Surgeons of England.

Sir,

Permit me to offer to you and to the rest of the Council very sincere thanks for the honour which you have been pleased to confer on me in electing me a fellow of your College.

I have the honour to be, Sir, your obedient and humble servant,

ERASMUS WILSON.

55 Upper Charlotte Street,

Fitzroy Square.

December 14th 1843 .

In the following two years, namely 1844 and 1845 , his private practice grew rapidly, due to his capabilities as a dermatologist and in particular his philanthropic disposition towards the poor. Scrofula was a very common condition in this era and was largely due, as were most of the skin ailments which he had to treat, to overcrowding and poverty among the majority of his patients. The poverty in particular must have been a real factor to him, for one of the most popular prescriptions to come from his pen used to read 'Summe the enclosed pound and call for another dose until well'.40

So it was that he resigned officially from the post of sub-editor of the Lancet though remaining closely connected with it both in advice on editorial policy and by numerous communications. He remained on the staff of the Middlesex Hospital continuing his anatomical teaching which was 'of a higher order and was of itself sufficient to have perpetuated his name'.41

As head of the department of anatomy he sent letters, in common with the departmental heads from other London teaching hospitals, to the President of the Royal College of Surgeons and to John South, when yet another inquiry was being made into the shortage of cadavers for teaching purposes. To South he wrote: ${ }^{42}$

Dear Sir,

I did not receive your note until yesterday (Monday) and in order to avoid loss of time I have addressed a note to the President of the Council noting the existence of scarcity and suggesting a cause.

After my note to the President was written I received Mr. Partridge's note calling a meeting 


\section{The Life and Works of Sir William James Erasmus Wilson}

of teachers for yesterday evening. At that meeting I apprehend that the subject was duly canvassed and I trust that something will be done by that body (Council of the College) to whom we ought to look in professional emergencies of various kinds and with the assurance of not looking in vain.

$$
\begin{aligned}
& \text { I am, my dear Sir, } \\
& \text { Very truly yours, } \\
& \text { ERAsmus wILsON. }
\end{aligned}
$$

and to the President of the Council he wrote more fully:48

Sir,

Having been informed that the Council of the College of Surgeons have kindly undertaken an enquiry into the supply of subjects for the anatomical schools; I beg to state on the part of the anatomical teachers of the Middlesex Hospital School of Medicine:

1. That the supply of bodies during the present session is inadequate to the proper instruction of medical students in anatomy.

2. That the deficiency so far as we are able to judge does not arise from any scarcity of unclaimed bodies at the various workhouses of the Metropolis but from the responsibility without reward which the act lays upon the masters of workhouses.

Under these circumstances I would respectfully suggest to the Council the propriety of assigning to masters of workhouses a small fee as a compensation for the trouble entailed upon them of giving notice to the Inspector of Anatomy of an unclaimed body and of granting the order for its removal.

December 16th 1845

I have the honour to be,

Your obedient servant, ERASMUS WILSON.

Regarding the supply of bodies, the letter to South, with its implied admonition to the College Council, serves to illustrate the power carried by the Councils of both Colleges and the Society of Apothecaries. Following the Burke and Hare murders in Edinburgh, Parliament had formed, in 1828, the Warburton committee, Warburton himself introducing a bill providing that unclaimed bodies from workhouses and elsewhere be sold for purposes of dissection. It did not, however, include provision for licensing of schools or for Christian burial of the remains. The Bill was opposed by the Archbishop of Canterbury and curiously enough by Thomas Wakley (and the Lancet!). The Bill was withdrawn in 1829 but reintroduced in 1831 , in an amended form, following the 'Italian Boy' murder by Bishop and Williams. 44 The two Royal College Councils petitioned Parliament for a legal enactment concerning cadavers and, in spite of Wakley's renewed opposition, the Bill was passed in 1832 . It must have been with these facts in mind that both these letters were phrased.

In August of the same year, 1845, Wilson produced his History of the Middlesex Hospital during the first hundred years of its Existence. The preface shows:

A desire on the part of the author to make himself acquainted with the early history of an institution with which he has been associated during the past five years.

That the book was never intended to reach general circulation may be seen from a subsequent paragraph: 


\section{R. M. Hadley}

The author feels it his duty to observe, also, that in undertaking the office of historian to the Middlesex Hospital he had no intention of making his labours public; his own views were limited to the presentation to the 'Weekly Board' of a manuscript account of the rise and progress of their institution up to the period of the termination of its first century.

However, the weekly board thought its publication might be of 'benefit to the hospital and therefore to the cause of charity by a diffusion of the information which it contains'. ${ }^{45}$ The number of copies printed must have been very small for today only two are in existence in London, one in the library of the British Museum and a specially rebound copy, presented to the Hospital with the author's compliments in 1867 , in the library of the Middlesex Hospital Medical School.

\section{The Hounslow Flogging Case}

On 15 June 1846 Private John White of the 7 th Hussars, stationed at Hounslow cavalry barracks, was sentenced by the District Court Martial to one hundred and fifty lashes with the cat-o-nine-tails for an assault upon his sergeant. The sentence was to be carried out by two regimental farriers in the presence of his Colonel and the regimental surgeon, Dr. Warren. This was an insignificant trial in itself but the subsequent death of Private White, the presence of Thomas Wakley, M.P., as the new coroner of Hounslow and the post mortem examinations and evidence of Erasmus Wilson were to have such far reaching effects and make such a difference to the latter's public standing that the court proceedings are worth relating in detail.

Wakley was by then well established as editor of the Lancet and a well known public figure; he was responsible for many changes in medico-legal proceedings and for parliamentary upheavals. On 25 February 1839 he was appointed coroner to the West Middlesex division and in this post became responsible for the inquest into John White's death. The evidence was such that it became necessary to adjourn proceedings no less than ten times and the story runs as follows.

Following the administration of his punishment 'which he took manfully', White walked to the station hospital where he remained as an inmate from i5 June until his death on I I July. During his stay in the hospital the ward-book records and correspondence to the Director General of the Army Medical Services showed that two pathological conditions were manifest. It seems that at first a period of recovery was observed, followed abruptly by deterioration with signs of cardiac and pulmonary involvement, pleurisy and pneumonia, leading to complete exhaustion and death. When the latter signs became evident Dr. Warren and Colonel Whyte had the foresight to note the scandal which might ensue should White die in the same hospital, so they sent a letter to this effect to the Director General of the Army Medical Services, then Sir James McGrigor.

Sir James instructed a staff surgeon of high repute, Dr. John Hall, to attend the case in order to ascertain the precise condition of Private White and duly 


\section{The Life and Works of Sir William James Erasmus Wilson}

make a report as to the exact condition of his illness. Dr. Hall arrived at Hounslow just in time to witness White's death and so worded his report to state that on the day he was due to be discharged from hospital he suddenly developed the systemic condition which ultimately caused his death. He did not think that the flogging was responsible. Fortunately he added the rider, hoping to cover both himself and the Army Medical Services, that the true relationship between flogging and death could only be accurately determined by a post mortem examination.

This was duly performed by Doctors Hall and Warren and an assistant, Dr. Reid. The report signed by these gentlemen stated that the injuries due to the flogging had healed and that, owing to his confinement to bed during the last days of his illness, the discolouration found on the back of the subject was due to a 'gravitation of blood to the parts'. In addition to this there was evidence of previous pulmonary and cardiac disease and gross hepatic enlargement.

The episode would therefore have been over but for the Vicar of Heston, to whom the Regimental Sergeant Major applied for burial. On seeing the death certificate the Vicar noted a difference between its wording and the reasons given him verbally for White's death by the Regimental Sergeant Major and he therefore requested that a report be made to the coroner before he would accept the body for burial. In his own comments to Wakley he mentioned that he was quite perturbed by the unusually short time, namely five weeks, which had elapsed between the date of the flogging and the death of White. Wakley ordered an immediate inquest which opened two days after the first post mortem examination.

In the evidence it appeared that Private White had, during the few days immediately prior to his death, become paralysed over his right side and lower extremities, being incontinent both of faeces and urine. In spite of this finding no examination had been made post mortem of the spine or spinal musculature by the officers so appointed. Wakley then directed the jury to appoint an independent local surgeon to make a more detailed examination of the cadaver and report to the assembled company on his findings. The inquest was then adjourned for the first time.

Five days later when the hearing was resumed it became evident that this surgeon also had omitted to examine in detail either the spine or the accompanying muscles and Wakley thereupon ordered a second adjournment and directed the jury to request that a reputable London surgeon be called in to examine the subject and supply the necessary information. This directive enabled Wakley to subpoena his personal friend, Erasmus Wilson, who he knew would be able to supply the information in a manner suitable for his purposes as coroner.

The competence and astuteness of Wilson's work now became evident. On the third and fourth hearings the medical evidence was completed. It showed that Private White had, in addition to the punishment received, been forced to fast for seventeen hours previous to its administration, refused even a basin of tea after receiving it and been forced to walk some two hundred and fifty yards to 


\section{R. M. Hadley}

the hospital. The ward-book records of the medical examination made on his admittance to hospital described multiple lacerations extending across the back from the neck to the loins, the largest being six inches long and five inches wide. The wounds were dressed with fomentations of warm water and cetaceous lead ointment. Poultices ordered for boils appearing some ten days later on his back, which appeared to be 'much inflamed and freely discharging', were never administered. Fifteen days later the ward-book mentioned poultices and purgings and it appeared that the patient was well enough to perform light manual work and 'volunteered' to clean a small outhouse.

Soon after this, however, his condition deteriorated day by day with the onset of pneumonia and pleurisy (this latter treated by purgation and the letting of thirty-two ounces of blood!) Five days later he was transferred to a medical ward because of his loss of bladder function and right sided paralysis. The paralysis extended rapidly from the lower extremities to his abdomen and chest and he died in a state of shock and stupor. Such was the nursing evidence elicited by Wakley in Erasmus Wilson's presence.

In contrast to this, the medical officer, Dr. Warren, who incidentally was not sworn, stated that the subject's back was nearly well at the end of the fortnight and his intention had been to discharge the patient on the following day. The other, and in Dr. Warren's opinion, separate condition of pleurisy and cardiac disease had supervened on the day of intended discharge with the resultant effects mentioned by him in the joint certificate sent to the Director General. Doctors Hall and Reid and the locally appointed surgeon, Mr. Horatio Grosvenor Day, then concurred in their evidence that death was due to pneumonia and pleurisy.

Erasmus Wilson, now having been lecturer at the Middlesex Hospital for some six years and with published writings gaining him considerable fame, came to give evidence which threw the opinions of the previous medical witnesses into disrepute. Such was the publicity aroused by the early adjournments that Wilson had much to lose should the verdict be contrary to his opinion and so prove him incapable.

His then had been a post mortem examination of the back only. His findings showed, firstly that the spinal muscles were in a state of extreme disorganization even to the deepest layer and secondly that the contents of the lower part of the spinal canal were in a state of decomposition. He put to the jury therefore two questions. How did the pulpy and decomposed state originate? Could this condition have any effect upon the interior organs particularly those of the chest? Having posed these very pertinent and erudite questions Wilson then began to support his theory that Private. White would be living were it not for the flogging.

The corner-stone in this theory, he explained at some length, was his observation that the disorganized spinal muscles, pleurisy and paralysis were all found on the right side. The interconnection between the muscle condition and the pleurisy could be accounted for by the very close approximation between these muscles and the pleura in that region in the normal subject. Finally he went 


\section{The Life and Works of Sir William James Erasmus Wilson}

further to suggest that ante mortem change in the muscles could have occurred due to extreme spasm resulting from intense pain.

Mr. Horatio Day who had been Mr. Wilson's assistant at the autopsy would not now give any definite views about it and the army surgeons remained steadfastly adherent to their statements. Wilson, in spite of a turn of face by $\mathrm{Mr}$. Day, who then committed himself to the view that only the external intercostal muscles showed any change, went on stage by stage, with the anatomist's care he had learnt from Quain and Langstaff, to put forward his arguments. 'There were again good reasons why', he said, 'the internal organs could have been affected by skin lacerations' and quoted analogically the well known relationship between visceral lesions and superficial burns. Finally he pointed out that, as any anatomist would agree, there were no internal intercostal muscles in the area affected with pleurisy and so Mr. Horatio Day's remarks counted for nought. So the case was closed after ten adjournments and Wakley summed up.

The jury returned a voluminous verdict amounting to one hundred and fifty words concluding:

... that by means of the said flogging the death of the said Private White was caused.

and adding a rider in the strongest of language expressing their horror and disgust that the law of the land permitted the flogging of British soldiers and imploring:

Every man in the kingdom to join hand and heart in forwarding petitions to the legislature, praying in the most fervent terms, for the abolition of every law and order which permits the disgraceful practice of flogging to remain one moment longer a slur upon the humanity and fair name of the people of this country.

Upon Wilson's evidence and capability therefore hung the future punishment of British troops, and the 'winning of his case' only served to improve his already brilliant reputation. The situation again seemingly complete was not allowed to remain so. Public feeling, newspaper criticism and comment rose to fever pitch. Wakley, already well versed in defending the soldier's cause on the subject of flogging, now found himself the object of considerable abuse from those who, for reasons either political or obscurely judicial, advocated flogging. The matter came to the attention of Parliament and there Wakley had to defend both himself and Wilson. An author describes Wilson on this occasion as

... only thirty-seven, and by no means the important figure in medical science or politics he was twenty-five years later, simply a rising young man.

The public, in view of the reports of Wilson's evidence given alone against Mr. Horatio Day and three military surgeons, considered the latter gentlemen to be 'somewhat tainted in outlook'. Regarded from the purely medical or scientific aspect, however, Wilson's evidence can be presented in quite a different light. He was placed in the uneasy position of presenting a pathological condition which he could give no definite reason and which was certainly unknown to 


\section{R. M. Hadley}

science. Additionally, his analogy between burning of the skin and visceral lesions was, after all, only an analogy and not founded on any scientific fact. Much of his communication with the Lancet during the summer of 1846 was therefore devoted to eloquent papers substantiating his arguments.

The rights and wrongs of his evidence and the resultant decision may be debated at length. One thing however is clear; the jury's pathetic rider to Wakley's strongly worded verdict was due solely to Erasmus Wilson's assertion, supported by the manner of presentation of his evidence, that had it not been for the flogging Private White would have been alive and serving his Queen and country.

The public outcry had such immediate repercussions upon Her Majesty's forces, and the existing army act, that when in 188 I Parliament altered the act to abolish flogging few persons knew that it was still sanctioned by law of the land.

\section{General Practice and Writing}

When the Hounslow trial had at last ceased to occupy the minds of the public and the members of parliament Wilson settled down to his large general practice and his life's work; from his pen came, during the next thirty years of his life, numerous volumes both large and small concerning diseases of the skin and allied or related conditions. His public life was not to begin until the end of this period, which might really be regarded as the time of unconscious consolidation of a good position won by youthful brilliance. Sir James Paget, in a speech at Margate made two years after Wilson's death, in May I886, said of these middle years:

In this branch of practice he soon prospered. He made a large income and became very rich but he made his income fairly; he never extorted money. He never grasped at it and never took it from the poor.... The use of his wealth was in itself remarkable and rare. With a gradually increasing income he scarcely increased his expenditure. . . . He passed his time with scarcely any change in the old method of his living and thus it was that his wealth grew unconsciously.

Using the clinical material presented to him in his consulting room he began his folio on Portraits of the Skin in 1847 , the work being illustrated by his own careful drawings, a skill in which he had already demonstrated his proficiency. In the same year also, his great friend, John Churchill, published his small volume On Ringworm: Causes Pathology and Treatment. The work on Portraits occupied him in part for the next eight years ${ }^{46}$ but in view of the existing living conditions it is not surprising that such an exhaustive range of conditions should have come before him during such a short period as eight years.

On Saturday, 23 December 1848, Erasmus Wilson was again called upon to 'defend' Wakley in court, ${ }^{47}$ on this occasion as a witness in a libel action brought against his friend by Healey, a doctor and barrister. Wilson's evidence was called concerning a cross accusation by Healey that Wakley 'puffed himself and reported his own operations in advertisements inserted into The Times and other newspapers'. 


\section{The Life and Works of Sir William Fames Erasmus Wilson}

The proceedings showed that Wakley, appointed surgeon to the Royal Free Hospital in 1847 had performed two successful operations, under ether anaesthetic, for the amputation of the arm at the shoulder joint. It is interesting to note that one patient aged eighty-two had been discharged from St. Bartholomew's Hospital as being incurable. It so impressed one of the witnesses of these operations that he sent a paper to the Lancet about it. Healey maintained that the operations never took place. It seemed from other witnesses that Healey was editor of a magazine, The Medical Times, and must have borne quite a strong grudge against Wakley. The judge, Lord Chief Baron, Pollock, commented upon the trivial and unfounded nature of Healey's accusations, giving judgement in favour of Wakley and awarding him costs and a fine of forty shillings.

In the same year the Lancet ${ }^{48}$ published a short series of annotations by Wilson on a diversity of subjects, the first concerning 'A Case of Intracranial Hydatis'; he describes a case seen in his father's practice (when he was only fourteen) about which he had made post mortem notes. These notes were still in his possession and their report showed Wilson's amazing powers of observation and reporting ability even at that early age. The second report concerned a case of 'A rare form of cutaneous eruption'. 40 This condition had been frequently confused with that state known as 'rubeola with erythema' and Wilson pointed out that such cutaneous eruptions should be called 'roseola punctata' and so originated the name 'Roseola'. The remaining reports are observations on the new substance collodion ${ }^{\text {b0 }}$ 'supplied to me some four months ago, being a solution of gun cotton in sulphuric ether and manufactured by Messrs. Bell of Oxford Street'. It appeared to be a very convenient substance for the covering of skin in certain conditions, in particular in the arresting of haemorrhage from leech bites.

Keloids drew Wilson's attention ${ }^{51}$ in the early part of 1849 . The Lancet published the context of a paper he read to the Royal Medical and Chirurgical Society in April of that year entitled 'On Keloids: Observations with illustrative cases'. In June ${ }^{52}$ he again formed public alliance with Thomas Wakley in the shape of a letter to the Lancet agreeing with the use of glycerine as a cure for deafness.

At the mid-century came the second of Wilson's major works on skin diseases. Printed in the first instance as a long series of articles in the Lancet and later (1852) published in book form, there appeared Wilson's Clinical Illustrations of Cutaneous Syphilis-having special reference to its pathology and treatment. In the introductory paragraph to the first article he sums up the objects of the work:

In the following series of papers I propose to relate a series of conditions illustrative of this interesting and important disease and entwine the narrative and practical deductions as their peculiar features suggest. The cases have all fallen under my care and treatment in the past few years and have been noted down from time to time for my own instruction. From a recent perusal however they have appeared to embody a number of facts which, from their bearing on the moot points in the pathology and treatment of syphilis, I thought might be acceptable to the profession. 


\section{R. M. Hadloy}

The third major work, started eight years previously and published in 1855 some two years after the appearance of Wilson's edited version of Hufeland's Art of Prolonging Life, was the folio Atlas of Portraits of Diseases of the Skin. This was followed a year later by a series of articles in the January to May issues of the Lancet, this time on 'Leprosy' including a short historical account of all the various regional types and 'a description of the forms under which leprosy exists in Britain at the present day'. Ever prolific in his writing, the decade was not to pass without the publication of a bulky little volume bearing Wilson's name and entitled $A$ three weeks scamper through the Spas of Germany and Belgium.

Life, however, was not all writing and medical practice for Wilson. On 23 April The Times carried the small notice:

On April 22nd the Silver Medal of the Royal Humane Society was awarded to Mr. Erasmus Wilson, F.R.S.

It is not clear as to exactly what the circumstances were which merited the award but this much is known: Olivier Green, a young lady of uncertain age, fell into the Regent's Park Canal and Wilson apparently being a capable swimmer was able to rescue her. An intrepid performance by a man of fortyeight, not athletically inclined, and performed in late winter. All the more remarkable if Sir William MacCormack's remark be remembered:

Wilson used often and most hospitably to entertain his friends. He was fond of giving large dinner parties at one of the great Iondon clubs and after dinner was wont to toast his guests in a long speech.

The 1860 's were less productive for Erasmus in the field of medical literature and more so in field of finance. In fact from 1860 to 1868 only three works were published, The Eastern or Turkish Bath and its History in 1861, and The Students Book of Cutaneous Medicine and Diseases of the Skin, together with A Statistical Inquiry into Causes, Frequency and Duration of Skin Disease, both in 1864. In the financial sphere on the other hand his wealth was seen to be accruing rapidly. Judicious investment in gas and railway shares during the 1850 's - a period when these undertakings were only just beginning to make headway-was now reaping its rewards. In spite of this, however, a certain amount of his wealth was not to be destined to remain long in his own pocket, as can be evidenced by bequests in later life and a passing remark by MacCormack:\$3

The amount of good he did privately will probably never be known as he was so unostentatious in regard to his charity.

Only two distant rumbles disturbed the 'calm before the storm'. The first, in the 12 November issue of the Lancet, was an unsigned and rather offensive letter asking three questions which shed light on an aspect of Wilson's ambitions hitherto unforeseen. 'Amicus' wrote:

While the discussion on the formation and downfall of St. John's Hospital is still proceeding it would be satisfactory to the profession if Mr. Erasmus Wilson would state how he became 


\section{The Life and Works of Sir William James Erasmus Wilson}

connected with that institution. At the same time he might explain his association with the London Journal as its medical editor, in which capacity he gave gratuitous advice on diseases of the skin and their treatment, in the columns of that periodical to any person who addressed him. The friends of Mr. Erasmus Wilson have also regretted to observe his name on the labels of certain hair washes and pomades.

Wilson replied the following week answering each of the accusations in turn. He had collaborated with Doctors Tilbury Fox and Frodsham to found a hospital for skin diseases. They were halted at the final stages of the arrangements and eventually found that a Mr. Milton had a suitable hospital in Westminster under the name of St. John's. Milton went to Erasmus Wilson and placed the hospital at his disposal, but seemingly the project was a failure.

During the years from $1864-9$ Wilson became a noted specialist in what was by now the rapidly developing field of skin diseases. As his obituarist in the Lancet writes: ${ }^{54}$

He knew more about skin diseases than any man of his time. He cured when others had failed to cure; and his works on dermatology, though they met with pretty searching criticism at the time of their appearance, have nearly all maintained their position as textbooks.

and a later author ${ }^{55}$ regarding some aspects of his methods of treatment:

... he had to deal with rich patients as well as poor and over these the masterful stamp of his mind enabled him to exercise despotism in matters of diet. Wilson was not only a consummate dietician but he knew how to make his patients submit to have their bodies placed under martial law.

A review published in the Lancet in the latter half of the year $1864^{56}$ of three works by Tilbury Fox, Alex Squire and Erasmus Wilson says of the last author's work:

The first author on all these matters is Mr. Erasmus Wilson; he has long been so, and so apparently he is determined to remain. The brochure of this work shows it to be limited to the middle and upper classes of society; such cases as fall within private practice. Such an accurately registered series of cases by a competent observer supply valuable material for further researches and this little volume possesses true scientific interest.

In some respects these successes may be likened to those of the poet, painter or musician talented and fortunate enough to be honoured in his or her own lifetime, though it would seem that in a profession such as medicine it is much more common practice for true greatness and achievement to receive its just reward in the lifetime of its possessor.

The mill pond surface of Wilson's life was not to remain unruffled for long. For reasons which are difficult to ascertain clearly-they may have been motivated either by desire for reform and improvement or simply by wish for public recognition-Erasmus began to covet a seat on the Council of the College of Surgeons. The first hint of this came in the form of a letter to the secretary 57 on 5 June 1864 : 
Dear Sir,

May I request the favour of your laying before the Council the enclosed documents by which I claim to be admitted a candidate for a seat in the Council on the occasion of a vacancy.

I have the honour to be, dear sir, Your faithful servant, ERASMUS WILSON.

Edward Trimmer, Esq.,

7 Henrietta Street, Cavendish Square. June $5 / 65$.

Secretary,

The Royal College of Surgeons.

The nature of these documents is not known but surmise would suggest certificates and degrees, letters of introduction, references and similar credentials. Trimmer's reply has not been preserved either but its contents were such that Wilson's application, renewed publicly in 1868 in the shape of a letter dated 12 March to the Lancet (i. 390), was not granted until 1870.

\section{The First Fournal of Dermatology: 'Lichen Planus'}

Journals of various types were very numerous, particularly in the field of medicine. Many people were anxious to publish and the success of a number of these weekly and monthly magazines, headed by the British Medical Fournal and. the Lancet, attracted numerous less capable men to found and edit publicationsmore with the prospects of fame and financial reward than from a desire for wider dissemination of scientific knowledge. Most of these mediocre enterprises met with the success they deserved but not a few, Wilson's fournal of Cutaneous Medicine included, faded into obscurity through no fault of their own. In 1867 Wilson founded his paper as 'A quarterly record of diseases of the skin' ${ }^{.88} \mathrm{He}$ remained as the editor for two years and then passed it into the hands of a Dr. Purdom of Belfast, under whose control it continued to circulate for another year before it disappeared. ${ }^{59}$ The reasons for its transfer into other hands

were not due to the financial loss incurred by a journal of this nature with its small circulation, but because most authors preferred publishing in journals with a wider reading public. ${ }^{80}$

If the presentation of this magazine did nothing else it revived interest in this speciality which had begun to flag considerably since the death in 1821 of Thomas Bateman-famous for his Synopsis of Cutaneous Diseases (1813). It also became the vehicle for Wilson's masterly and definitive descriptions of 'Lichen Planus' 61 and 'Nevus Araneus' ${ }^{62}$ or the spider naevi of liver disease. Finally from this journal, as Bettany says: ${ }^{\text {B3 }}$

Wilson was much pleased to be the means of bringing forward a little work on 'Infant Life: its Nurture and Care', written anonymously by a lady, and first published in his 'Journal of Cutaneous Medicine'. In his preface to it he expressed his strong beliefs that hygiene is the first necessity of a scholastic institution, that with proper nurture almost all the diseases of infants 


\section{The Life and Works of Sir William James Erasmus Wilson}

would be extinguished, that illness following vaccination properly performed can only occur owing to neglect of proper nurture and care and that 'healthy children can never suffer, never die from vaccination'.

\section{The Chair of Dermatology}

At the age of sixty, in the year 1869 , the storm of public life broke over Erasmus Wilson. His yearning for the seat on the Council of the Royal College, evidenced some five years previously, had been increased by frustration. His wealth, rapidly enlarging as a result of the successful development of the gas and railway projects in which he had invested, accumulated through lack of suitable outlet. Realizing, perhaps, the value of his assets and more general use to which they could be put he decided to endow a Chair of Dermatology at the Royal College. The first hint of this came in the form of a letter written to Stone, Edward Trimmer's successor to the post of secretary, concerning the deed of trust being prepared: ${ }^{64}$

My dear Stone,

Sunday, July $4^{\text {th }} / 69$

Do me the favour to read this and, if you approve, put it in an envelope and send it to the Gazette. I will call on you tomorrow (Monday) in the afternoon.

$$
\begin{aligned}
& \text { Yours very faithfully, } \\
& \text { ERASMUS WILSON }
\end{aligned}
$$

Stone approved the letter and four days later on 8 July the deed of trust was signed. Under its agreements Wilson gave:

To found and endow a Professorship of Dermatology with the object of promoting the study of the pathology together with the anatomy and physiology, human and comparative, of the skin and its appendages.

The amount donated was $£ 5,000$ in 'New, three per cent consols'-a very firm investment at the time. In recognition, either of his gift or of his status, the Council appointed Erasmus Wilson to the post of Professor and to his coveted seat on the Council. He maintained the position from 1870-8 delivering six lectures annually, always during the first three months of each year. The lectures, given from 1870-3, were extensively reported in the Lancet and after the first series that journal's correspondent mentions the assistance given in

the following and elucidation of the substance of each lecture, by drawings, casts, and wax models of the various conditions under discussion.

These 'visual aids' had been prepared and donated by the lecturer himself!

The individual lectures themselves were woven into a pattern following Wilson's characteristic systematic approach to his subject. On each occasion he opened by a brief summary of the preceding discourse and continued with an individual topic allied to those being considered during the relevant series. The best impression of the comprehensive nature of this course can only be gained by examining the following summary of the lecture headings: 


\section{R. M. Hadley}

\section{SCHEME FOR WILSON'S LECTURES IN DERMATOLOGY}

1870 I. History and development of dermatology.

2. Eczematous affections: Lichen Planus-treatment.

3. Treatment of erythema, furunculus and pemphigus.

4. Inflammations. (1) From poisons. (2) Constitutional causes. (3) Traumatic cases.

5. Nutritive affections.

6. Diseases of the nails, of colour, the hair, sebaceous and sweat glands.

1871 I. Review of last year. The seven divisions of inflammation.

2. Eczema and its varieties.

3. Squamous eczema or pityriasis and psoriasis.

4. (not recorded).

5. All forms of treatment for eczema.

6. Treatment of infantile eczema.

1872 I. Review of the author's system of classification. Erythematous reactions.

2. Erythema and erysipelas.

3. Phlyctenous affections: Herpes, Common inflammation of the skin.

4. Specific inflammations particularly those in the 'College collection'. Rubeola, scarlatina, etc.

5. Models of cutaneous syphilis in the College collection.

6. The regular course of syphilis.

1873 I. Review of the previous lectures.

2. Consideration of the models and specimens of syphilis and other conditions received

3. by the College from France. New diagnoses of these conditions.

4.

6.

Leprosy and its treatment.

Judged by present day standards his ability as a lecturer was not high. It is the custom of recent years for medical lecturers to be as precise as possible and as impersonal as is suitable for the subject being taught. Wilson was neither of these. His orations, given in the same style as his writings, carried that irritating floral aspect so characteristic of Victoriana, the expressions ' $I$ have found ...' and 'My cases . . .' being by no means infrequent.

In the second lecture of the series given in 1873 Wilson devoted himself to a review and a 'rediagnosis' of a series of models and specimens received by the College Museum from France during the previous month. Apparently the model of pityriasis rubra was in actual fact that of Lichen Planus and similar glaring inaccuracies, not recorded, were to be observed. Wilson's comments were too scathing for French ears:

... do not enhance our respect for the present state of dermatological science in France. We think it is a good deal behind hand and is specially lacking in regard of pathological considerations and its professors know apparently little of the labours of foreign writers. 65

Besnier, in writing on the occasion of Wilson's death, ${ }^{86}$ could not resist having the last word in support of his own countrymen: (translation)

Far be it from us to reproach Erasmus Wilson for a few ill-founded criticisms which he levelled at several of our French authors and which escaped him in the improvisation of his lessons ... 


\section{The Life and Works of Sir William James Erasmus Wilson}

even less should we reproach him for his opposition to the doctrines of dermatophytology; they came too late for him; and besides they have, up to the moment, been in fact of so little assistance to dermatological therapeutics, that the harm he has caused has not been very extensive.

From this series of lectures one classical description emerged, that of 'neurotic excoriations' ${ }^{67}$ Hodgson-Jones (1955) ${ }^{68}$ regards this description as laying the corner-stone of psychosomatic dermatology. Coupled with this in 1870 Wilson published, in the Medical Times and Gazette, his description of Dermatitis Exfoliativa, regarded by Dorland ${ }^{70}$ and many others as 'Wilson's disease'. Such was the demand for the substance of these lectures that they were published in 1875 and the author's pride in them is evident from a letter to Stone: ${ }^{71}$

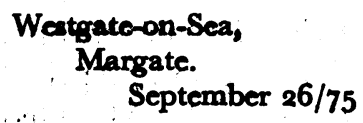

Dear Stone,

I have written to Augustus Churchill to send you 28 copies of my Dermatological Lectures just published. Will you do me the favour to distribute them ancong the Council; - one to the library -one to Flower:-one for your son and one for yourself.

Yours always faithfully, ERASMrus WTLSON.

It appears, however, that the pressing nature of public duties and the beginnings of systemic disease were to prevent Wilson from following the work to which he had devoted his life. The former comes to light from one of his frequent communications to Stone: ${ }^{71}$

My dear Stone,

July $10 / 76$

I no longer take in of read the Laviet-Wilks knows of my priority re finger nails in illnessbut I most bring you a copy of my Healthy Skin which will explain the matter to you.

I long for an hour at the College:-at: ny work. I have none other greater or worthier:-

ERASATU WreON.

P.S. I am glad you esteem the Boar's Head. ('Could this be tobacoo?')

The hint of illness appears in a letter to the same person excusing his absence in a rather engaging manner:

Westgate-on-Sea,

October 13/75.

My, dear Stone,

I have no better excuse for absenting myself from my duties than laxiness, 'vis inertid'. It is true I have plenty of occupation, planting and transplanting, and magrificent weather.

For the first month of my being here I was troubled by my liver-common seaside billiousness-but now that is passing away. I am really getting good from my stay here and am carefully utilising every hour.

Mrs. Fergusson (Mrs. Stone?) has given you a very proper Roland for your Oliver and proved herself master of the occasion. Seeing the dermatological lectures advertised and having been appealed to as to binding, I concluded that they were ready for delivery: but 'delays is human'. 


\section{R. M. Hadley}

Thanks for making me known to the curiosities of Boulogne: I hope you sent the catalogue by the Castalia that it might escape the concatenation of the Channel.

Always faithfully yours,

Thomas M. Stone, Esq. ERASMUS WILSON.

Did Wilson have to pay the cost of binding his 'Lectures'? Had he been on yet another foreign tour? These, unfortunately, are questions which will remain unanswered.

\section{Epsom College and Swanscombe Church}

Just as Wilson put his gifts to good and frequent use in his work at the College so he found uses for his wealth also, thereby earning a reputation in the field of philanthropy. Two years after his election to the Council of Epsom College, on I 7 April 1870, he built the Headmaster's Boarding House, a building designed by Mr. George Elkington and erected at a cost of $f_{55}, 058$, Erasmus himself laying the foundation stone on I I October $1872 .{ }^{72}$

This charitable foundation must have been a very worthy outlet for Wilson's finances. It was founded

To assist medical men by educating their sons well and economically

beginning with a foundation of fifty boys. These youths had to be

children of medical men where circumstances had prevented these children from enjoying the usual opportunities afforded to the children of professional men.

Queen Victoria gave her patronage at the outset and even today the school is known as 'The Royal Medical Foundation of Epsom College'. Prompt subscriptions allowed part of the buildings to be opened in two years, but the supply of money rapidly became inadequate and the whole venture was faced with closure until the Lancet helped with the donation of $£_{1}, 000$. From then onwards constant support from the readers of that paper and from the paper itself made the school an economical proposition. Sir Erasmus Wilson's assistance is reported in a meeting of the Governors in $1885::^{73}$

In presenting their annual report to the Governors of the Royal Medical Benevolent College, the Council feel that their first duty is to pay a tribute of respect to the memory of their highly esteemed colleague, the late Sir Erasmus Wilson, F.R.S. who was not only a most generous contributor to the funds of the College, but for many years devoted much of his valuable time to attendance at its Council and Education Committee. The College was especially indebted to him for the Head Master's Boarding House at Epsom which was built entirely at his expense in 1873 and presented to the foundation.

Wilson's name is also perpetuated at the College by a prize named after him. This prize was established in 1880 by means of a subscription organized to endow 'A prize at the school in the name of Professor Erasmus Wilson'. The 


\section{The Life and Works of Sir William James Erasmus Wilson}

amount so subscribed was duly invested, and the prize, known as the 'Erasmus Wilson Carpentry Prize', is still in annual award to 'the junior boy who does the best work in the carpenter's shop'.

A year later, the same year as he received Freedom of the Turners' Company, 1873 , a call from the church of his youth claimed his attention. With the death of the Reverend Renouard the parish had 'fallen' under the guidance of one Reverend Candy, ${ }^{74}$ a dissolute gentleman. The running of a parish was not apparently quite in the Reverend Candy's line of business and at a meeting of the parishioners it was recorded that 'the condition of the church buildings was a disgrace to the Parish and an inconvenience to the worshippers'. Accordingly Candy raised a fund for its restoration and when the sum had reached $£_{200}$ was anxious to proceed with the work. Objections came at once from the Parish Council and 'a man came from London who said he would contact Mr. Erasmus Wilson and see what could be done'. Wilson's reply took the form of complete restoration of the tenth-century church. Up to 1873 the building had been flat roofed and the tower in a constant state of collapse but, following Wilson's benefactions, it was entirely rebuilt.

In appreciation of the work done the Parish Council erected a stained glass window, beneath which is affixed the following plaque:

The tower and nave of this church were restored in 1873 by Professor Erasmus Wilson, F.R.S. and this window was inserted by the Committee as a memorial to his great work.

In addition, the grave of his sister was moved to the church and the following tablet on the south wall of the side chapel records:

To the memory of Eliza Thomas Wilson, only daughter of William Wilson, Surgeon R.N., who from the full enjoyment of health after a few days of insidious and scarcely painful disease died 29th April 1835 in her 20th year.

EHEU!

Almost as if he had a surfeit of money, the Lancet of 1879 reports yet another of Wilson's gifts: ${ }^{75}$

\section{ANOTHER ACT OF GREAT BENEFICENGE BY ERASMUS WILSON}

He is to build a new wing for the Margate Infirmary, to contain wards for seventy patients, a tepid sea water swimming bath, and a chapel for three hundred persons. Estimated cost will exceed $£ 20,000$. Mr. Wilson has made good choice of an institution on which to spend some of his good intentions. Few infirmaries are of more practical value than the Margate one.

It is possible to distinguish a slightly acid tone regarding this venture and $\mathrm{Mr}$. Wilson's 'good intentions': no doubt this was engendered by the refusal a few years earlier to take in or read the Lancet! A number of persons will possibly doubt the good intentions regarding Cleopatra's Needle, especially when six persons were to lose their lives over it. 


\section{R. M. Hadley}

'Cleopatra's Needle'

Early in the 1870's Erasmus Wilson became interested in Egypt and archaeology. Some of his great financial resources were devoted to this hobby and he was able to exert considerable influence in this sphere as well as in medicine. It was entirely due to him that a Chair of Egyptology was founded at University College as long after his death as 1892 . The Foundress, Miss Amelia B. Edwards, had travelled extensively, in her youth, in Egypt and the Sudan. Since that time she had devoted herself to promoting the study of Egyptology in England both by her writings and by the foundation, in association with Erasmus Wilson and R. S. Poole, of the Egypt Exploration Fund. Wilson, elected president, used to deliver lectures to clubs and societies about the antiquities preserved in Egypt. At his instigation Miss Edwards took into her employ W. F. (afterwards Sir Flinders) Petrie, the noted archaeologist. When, late in the century, she determined to establish a Chair of Egyptology her choice fell upon University College because London alone was open to women students. ${ }^{78}$ Out of all the London colleges the choice of Wilson's old college seems too coincidental!

The obelisk known as 'Cleopatra's Needle' had been British property since I80 I when Sir Ralph Abercromby had claimed it during a British expedition in the French War. The soldiers 'were so pleased to capture this obelisk that each man payed a shilling towards the cost of its transportation from the original site to the shore', where a raft was built to bring it to England. Owing to the unlikelihood of its ever reaching the English shores the Government forbade any further plans to move it and the Needle was deposited on the beach.

Two Egyptian rulers offered the stone to Britain, Mehmet Ali in 1840 and the Khedive in 1877 . On each occasion the Government refused it on account of the cost of shipping such an unwieldly object over such a great distance. Erasmus Wilson thought this attitude on governmental expenditure 'derogatory to the National Dignity' 77 and offered to pay the expenses himself.

The Graphic reported (on 2 February 1878) the arrangements for its removal as what they called 'Professor Wilson's Narrative'.

Sir James Alexander wrote to me on professional matters mentioning about Cleopatra's Needle, which, unless we took it away, the Khedive would break up for building stone.

Wilson then goes on to speak of his meeting with Mr. Dixon, the engineer responsible for building the encasing vessel 'Gleopatra'.

A few days afterwards (the awarding of the site) I called upon Mr. Dixon. I soon found that Mr. Dixon was a Freemason, hence all formality and ceremony was at once banished (Wilson was himself a prominent Freemason). He told me he had long contemplated bringing the obelisk to England and hoped one day to do it himself when he should be rich enough.

Thence follows a long description of how the obelisk would be encased in a metal cylinder and floated to this country towed by a suitable vessel. 


\section{The Life and Works of Sir William James Erasmus Wilson}

Some further conversation took place and Mr. Dixon was so confident of his success that we said this: 'The undertaking is not an easy one; there may be unexpected difficulties; we must succeed; you say you can do it for $£ 7,000$; will you undertake to set it successfully on the banks of the Thames for $£ 10,000-$ no cure, no pay?'

'Willingly' was his answer and we parted. The following week the contract was drawn up and agreed to in terms and was signed in January.

Mr. Dixon proceeded with his task and the obelisk, safely cocooned in the metal shell of the 'Cleopatra', left Alexandria towed by the Olga, on 2 I September 1877. Unfortunately the vessels separated in a violent gale during the night of the $14 / 15$ October and six hands were drowned when they were washed overboard trying to save the towing cables. ${ }^{78}$ The Olga made a fruitless attempt at its recovery, finally proceeding London-wards alone.

Three months elapsed before any attempt was made to search for the missing 'Cleopatra' which, by that time, seemed a completely hopeless hunt. However, the search vessel found it adrift off the coast of Portugal and so towed it to Ferrol where it was beached and examined. The survey proved Mr. Dixon to be a sound engineer, for the casing was as whole as it was on the day of departure from Alexandria. Accordingly, refloating operations were put into action and the needle was towed by the Anglia under Captain Gater arriving in London on 20 January 1878 . Considerable controversy arose over salvage money and an award was finally made to Captain Cater of £2,000 which sum might account for the discrepancy between the Port of London Authority records, which put the cost of transport at $£_{15}$,000, and those of The Times and others, which quote Wilson as paying $£$ Io,ooo.

More discussion ensued about its final siting; this could not have pleased Wilson very much-for reasons which do not need to be stated. Eventually it was erected on its present site on the north bank of the Thames between the Waterloo and Charing Cross bridges. Plaques at the base of the monument give a survey of how it came into British hands and the contents of the pedestal are given as: ${ }^{70}$

The story of its erection, jars of Doulton Ware, a complete set of English coinage, a copy of the translation of hieroglyphics on the side panels, a standard gauge to one thousandth of an inch, a portrait of Queen Victoria, Bibles in various languages, Bradshaw's railway guide, a case of cigars, a feeding bottle, a map of London, copies of English newspapers, twelve photographs of pretty English girls, the Times, and, finally, a two-foot rule.

Wilson's final word on this subject came in the form of a small publication entitled Cleopatra's Needle, with brief notes on Egypt and Egyptian Obelisks, published late in 1878 .

\section{Vice President and President}

The Lectures in Dermatology given by Professor Wilson at the Royal College of Surgeons ended in 1878 when several suggestions were made to him to broaden their scope. Wilson resigned the Chair because of his extensive commitments-he had in the same year been elected President of the Medical Society 


\section{R. M. Hadley}

of London-and in the following year alterations were made in his donation so that it should include the whole field of pathology. The Royal College calendar records: ${ }^{80}$

The income derived from the fund should be devoted to the promotion of original researches by lectures delivered at the College, the number of such lectures not to exceed three in any one year and to be given by one or more persons to be called the Erasmus Wilson Professors of Pathology.

This included only Henry Trentham Butlin and Frederick Treves and in I88I further alterations were thought desirable. Under a new 'Deed of Trust' dated I3 April I 882 it was provided that the income of the fund should be appropriated in part towards the payment of the salary of the Curator of Pathology Museum. The lectures were to be given by the Curator himself, or some other person appointed for the purpose, and given the title of 'Erasmus Wilson Lecturer'. Three lectures were then delivered annually from 1882 to 1908 , in which year it was decided to institute a series of six lectures or demonstrations, incorporating the Erasmus Wilson lectures in these six. The honorarium today stands at $£ 30$.

Following his resignation from the Chair of Dermatology the College Council elected him Vice President, a post he held in 1879 , and in 1880 he succeeded Sir John Erichsen, his contemporary at University College in the early I840's, in the post of President of the Royal College of Surgeons. Vanity Fair ${ }^{81}$ published a cartoon portrait of him by Spy entitling it 'The Obelisk'.

The caption reads:

... the relic of an immodest cult (Cleopatra's Needle) and the testimony to the public spirit of an excellent surgeon. He is a man of merit and modesty; and he declined to be made a Knight Bachelor.

The tempting offer of a knighthood, in those days an infrequent occurrence, must have eventually overcome his resistance, for in the following year, $188 \mathrm{I}$, The Times of 7 December ${ }^{82}$ states:

Her Majesty has been graciously pleased to confer the honour of knighthood upon Mr. Erasmus Wilson, P.R.C.S., in consideration of his munificent gifts for the support of hospitals and the encouragement of medical study.

So came the crowning glory to a life's work, President of the Royal College of Surgeons and Knight Bachelor at the age of 72. In spite of all these honours Wilson was not to rest in glory. On 3 August he gave an address to the College as President of the section of dermatology. ${ }^{83}$ In it he concerned himself with a rational approach to the treatment of diseases of the skin. He concluded:

What I have said is intended to open up to the minds of my hearers a picture of the broad field in which we all labour: . . . 
Still honours flooded upon him: the Biblical Archaeological Society ${ }^{84}$ made him its President and he gained the honorary freedom of the Clothworkers Company of the City of London. ${ }^{85}$ For the former Society he produced 'The Egypt of the Past', which was unfortunately to be his penultimate public communication.

\section{Last Days}

Ill health began to curtail his public activities and the Lancet $^{86}$ records the following reports, the first on 22 April I882:

We are glad to be able to announce that the health of Sir Erasmus Wilson is improving. Sir Erasmus' illness began with an attack of acute dyspepsia attended with a considerable amount of febrile disturbance. From this he has in great measure recovered though he is still suffering from a catarrhal condition of the bronchial mucous membrane. Though the above combination and succession of ailments are, we need scarcely say, of grave import, we may hope that with the continuance of genial weather, convalescence will be speedily established.

and again on 29 April: 87

We are able to report that the health of Sir Erasmus Wilson has improved during the past week in spite of the infavourable state of the weather.

During the following weeks his health seems to have improved considerably, the last report appearing at the beginning of July: ${ }^{88}$

A few days since, Sir W. Jenner, Dr. Wilson Fox and Dr. R. Liveing held a consultation respecting Sir Erasmus Wilson's health. They decided that he should pass the summer months at Westgate-on-Sea.

Maybe the cause of the malady lay in the original liver disorder he mentions in his letter to Stone some seven years previously.

His physical health was not to prevent him working, and in the next year came his last book, The Recent Archaic Discovery of Ancient Egyptian Mummies at Thebes, which was a printed form of his last public lecture, that given to the Young Men's Christian Association at Margate on the I5 February 1883. Later in the same year he made donations of money and specimens to the Royal College Museum. The latter benefactions included the remainder of his models of diseases of the skin and of related pathological conditions. In memory of his father he endowed at Aberdeen University a Chair of Pathological Anatomy at a cost of $£ 10,000$.

His health now began to fail rapidly and during the summer of 1883 he became totally blind, unable to work or lecture, restricted to living quietly in 'The Bungalow' at Westgate. He resigned his membership of the College of Surgeons Council in I 884 , and on Io July I 884 the following minute is recorded from the College Quarterly Council: ${ }^{89}$ 


\section{R. M. Hadley}

Sir T. Spencer Wells Bart., in pursuance of section three of the standing rules, handed to the President a statement signed by himself and five other members of Council nominating Sir William James Erasmus Wilson, F.R.S., a fellow and past President of the College, as the recipient of the Honorary Gold Medal of the College.

The statement included the words:

We the undersigned ... . in recognition of his great liberality in his contributions to the Museum, in the endowment of the Pathology Curatorship and in the foundation of the Professorship with which his name will always be associated and held in honour.
James Paget
T. Spencer Wells
John Erichson
John Marshall
W. S. Savory
I. Cooper Foster.

So Erasmus, on his death-bed, became the seventh holder of the honorary gold medal since its inception in 1800 , following the path of the greatest, and to be followed by such men as Sir James Paget, Lord Lister, Viscount Nuffield, Sir Alexander Fleming and Lord Webb-Johnson.

One week later he became 'seized with an inflammation of the bowels' and died at his home on the 7 August 1884 .

The Blessing of Him that was ready to perish came upon me and I caused the Widow's heart to sing for joy.

The funeral took place on 13 August in the church he helped to restore at Swanscombe, where his remains were interred in a special vault. The number of mourners was large and a special train was run at II.30 a.m. from Charing Cross to Northfleet Station. During the service the oration was given by the Reverend H. Woods, Vicar of St. Edmund's, Manchester. ${ }^{92}$

His widow died some two years later and is buried with him, the combined tomb being marked by a plaque on the north wall of the Chapel in Swanscombe Church. His vast wealth reverted, on the death of Lady Wilson, to various charitable bequests. The bulk of the fortune was received by the College of Surgeons and amounted to $£ 209,617$ I6s. 8d. Its use was immediate, allowing the Council to make considerable extensions to the existing buildings on the south side of Lincolns Inn. These included laboratories and workrooms, the pulling down of number 39 Lincolns Inn Fields, extensions to the library and a new house for the Conservator of the Museum. To the Royal Medical Benevolent College at Epsom he gave $£ 5,000$ and to the Sea Bathing Hospital at Margate a further $£ 5,000$.

To estimate the value to medicine and to the world of the life of Erasmus Wilson would be not only impossible but presumptuous and the most apt epitaph is to be found in the Annales de Dermatologie et Syphiligraphie where Ernest Besnier ${ }^{93}$ wrote:

Au dessus de tout, il avait ce rare mérite devenu trop rare d' l'spoque actuelle, d'être médecin en meme temps que dermatologiste! 


\section{THE WRITINGS OF ERASMUS WILSON}

The published works of Sir Erasmus Wilson are given in the following list in chronological order. Numerous works, published in journals and in the form of isolated papers, are quoted after the main summary owing to an absence of any specific reference. No attempt is made to give a critical opinion of these writings and the descriptions are only illustrative of the contents of the works to which they refer.

1837-42 A Series of Anatomical Plates Illustrating the Structure of Different Parts of the Human Body, edited by J. Quain and E. Wilson. London, vols I-v.

This work was begun by Jones and Richard Quain in the early 1830 's. Wilson began his association with it by editing in 1837 the volume devoted to the Vessels of the Human Body. He then assisted in the editing of the remaining volumes until 1842 . The size of these 'folios' is approximately $19 \mathrm{in} . \times 12 \mathrm{in}$. and the five volumes bound together, published in 1842 , constitute a book of $3 \frac{1}{2}$ in. in thickness!

The aim of this publication was given as 'the supplying of the wants of students at a moderate price' ( $£ 2$ I $6 s .0 d$. per volume). The names of parts are given in English, Latin and French accompanied by a running comment on each plate.

Vol. I The Muscles of the Human Body.

II The Heart and Blood Vessels, Lymphatics and Lacteals.

III The Brain, Spinal Marrow and Organs of Sense.

IV Organs of Digestion, Respiration and Secretion.

$\mathrm{V}$ Bones and Ligaments.

1838 Practical and Surgical Anatomy. London 1838.

1839 The Anatomists Vade Mecum. A System of Human Anatomy.

Published by John Churchill, in 1839 , this work was designed as a pocket book for students. Its popularity may be judged by the production of a fourth edition in 1847 and an eighth edition in 1861 . Bound in cloth, its cost was only twelve shillings.

1859 The Art of Prolonging Life-Hufeland, edited by Erasmus Wilson, 2nd Edition.

186. The Eastern or Turkish Bath and its History.

The work covers the history of this form of bathing, approving its recent introduction in Great Britain.

1864 The Students Book of Cutaneous Medicine and Diseases of the Skin.

Bound in cloth at sixteen shillings this work was intended as a students version of its counterpart of 1842 .

A Statistical Enquiry into the Causes, Frequency and Duration of Skin Diseases.

(The field covered by this work is found in the text.)

1865 On Food as a Means of Prevention of Disease.

(Tract.)

Observations on the True Leprosy.

Published lectures from the Lancet.

1870 Lectures on Ekzema: and ekzematous affections with an introduction on the general pathology of the skin.

These lectures are a reprint in book form of those first published in the Journal 


\section{R. M. Hadley}

of Cutaneous Medicine during the preceding three years. The appended essays and cases in the final chapter are extracted both from Wilson's own Journal and from other medical publications.

A Three Weeks Scamper Through the Spas of Germany and Belgium.

Beginning with an account in great detail of a holiday spent in these two countries, Wilson could not resist the addition of an appendix on the 'Nature and uses of mineral waters'.

1878 Lectures on Dermatology delivered at the Royal College of Surgeons of England I $876-7-8$.

The first series of lectures were published in 1875 and their popularity led to the publication of the last lectures given when Wilson was Professor of Dermatology. The author in the preface mentions the circumstances attendant on the founding of the Professorship together with his own gifts to the College. The substance of these lectures is given in the table appended to the text (vide supra).

1842 Diseases of the Skin: A practical and theoretical treatise on their diagnosis, pathology and treatment arranged according to a natural system of classification.

This was Wilson's most famous scientific work, reaching numerous editions. It formed the nucleus for his other works and contains the first system of classification of skin diseases to be published.

$1844 A$ History of the Middlesex Hospital During the First hundred years of its Existence.

The work covers the accounts, often verbatim, of the minutes and meetings of the Weekly Board of this hospital. The first part is limited to an account of the foundation, and subsequent chapters explain the functions and development of the various constituent bodies.

1845 Healthy Skin: A popular treatise on the Skin and Hair, their preservation and management.

Owing to its wide lay appeal this became Wilson's most famous popular work; being translated into Italian in 1855 and reaching its seventh edition by 1866 . The wide dissemination of the knowledge contained in this work was instrumental in the popularity gained by public (and private) bathing during the latter half of the nineteenth century.

1847 On Ringworm: Its causes, pathology and treatment.

Wilson here covers in just over one hundred pages Ringworm, similar diseases which may be confused as such, Alopecia Areata and other general and special diseases of the scalp.

1852 On Syphilis: Constitutional and hereditary and on syphilitic eruptions.

Dedicated to Philip Ricord, the acknowledged venerologist of the 1850's; Wilson attempts, by the use of specific cases, to explain the existence and nature of the 'poison unknown'. He devotes over half the volume to the diagnosis of skin eruptions due to syphilis and the remainder of the work to the hereditary and systemic aspects of the disease and the known methods of treatment.

1855 Portraits of Diseases of the Skin.

This was published in the same folio form as the anatomical series by Quain. Prefaced by the reasons for its publication, one whole page ( $15 \mathrm{in} . \times 20 \mathrm{in}$.) is devoted to the classification of skin diseases first published by Wilson in 1842 in Diseases of the skin. Each condition is illustrated by a coloured drawing, the whole work taking eight years to complete. The drawings were made by W. Bagg and originally published as they were completed, each being dated. 
The Life and Works of Sir William James Erasmus Wilson

Finally Wilson prints in a synopsis of the drawings, 'the order most suitable for binding'.

1855 Cleopatra's Needle: with brief notes on Egypt and Egyptian Obelisks.

Produced by Wilson at the behest of Miss Amelia Edwards, this little work was to supplement the already extensive newspaper reports of the time on the occasion of the erection of Cleopatra's Needle on the north bank of the Thames.

188I The Egypt of the Past.

1883 Ancient Egyptian Mummies at Thebes: The Recent Archaic Discovery.

The last work to be published, a year before Wilson's death, this volume of some thirty-five pages was the text of a lecture given to the Young Men's Christian Association at Margate of which Wilson was Vice President. The reason for the choice of this subject appears to be the close connection between Biblical and Archaeological knowledge.

\section{Other Writings of Erasmus Wilson}

'Identification of the terms used by Celsus VI, i-iv'一The Dermal Pathology of Celsus. 'Skin'-Cooper's Dictionary of Surgery. New Edition, II, 1872.

Report to the Leprosy Committee-Observations on the true Leprosy or Elephantiasis, with fourteen cases, 1865 .

Structure of the Ultimate Muscular Fibrit of animal life; On the Development and Growth of the Epidermis; On a remarkable alteration of appearance and structure of the human hair. (Papers to the Royal Society.)

An organic change of structure of the human hair produced by Syphilis.

Eczema Infantile.

Thermo-therapeia-the heat cure-or the treatment of disease by the immersion of the body in heated air.

The question of providing medical asylums for the lepers imported into this country from our Colonies.

Hairs growing upon the tongue.

$A$ case of Hydatids in the brain (see text for reference).

Wilson is also recorded as writing the articles on skin in Grant's Surgical Dictionary and Quain's Dictionary of Medicine.

\section{REFERENCES}

1. Contemporary Medical Men, I, 1888, 209.

2. Dictionary of National Biography, vol. LxII.

3. [I] p. 200.

4. William Hazel. Private Communication.

5. Dictionary of National Biography, vol. LXII; and BoAse, Mod. Eng. Biog., 3, 1950, 1901, vols. $1428 / 9$.

6. Baddeley, Sir John, Cripplegate: one of the 26 Wards of the City of London. Pvte

7. [4] printed, 1921. Guildhall Library.

8. [I] p. 200.

9. Treasurer's Documents, Royal College of Physicians Lond.-Box 4: Envel $4^{\text {I-Rep. to }}$ Treas., p. 14.

10. Newman, C., The Evolution of Medical Education in the Nineteenth Century, 1957, p. 37. 


\section{R. M. Hadley}

II. SPRigge, Sir Squire, Life and Times of Thomas Wakley, 1899, p. 26.

12. Atray, J. B., Sir Henry Wentworth Acland, 1903, p. 82.

13. [10] p. 48.

14. [10] p. 49.

15. ThORNTON, John L., John Abernethy, 1953, p. 65.

16. Roget, Peter, Human and Comparative Physiology; the first Lecture at the New School, 1826.

17. Fertor, Gharles Lett, Memorials of Fohn Flint South, 1884.

18. [1] p. 204.

19. [1] p. 204.

20. Univ. Coll. Hospital Med. School. Minutes, ii, 85 (cf. pp. 129-30).

21. Ibid., ii, 150-1, 157.

22. Ibid., ii, 316-17.

23. Strirlin.o, A. M. W., William De Morgan and his wife, 1923, p. 33.

24. [1] p. 205.

25. Often Called the English Hippocrates, Thomas Sydenham (1624-89)-Sydenham's Chorea.

26. Lancet, $1837, \mathrm{i}, 767$; Letter in reply to Mr. Kiernan.

27. Plarr's Lives of the Fellows of the Royal College of Surgeons of England, II, 535.

28. Lancet, 1839 , ii, 16 and 333.

29. Lancet, 1840, pp. 249-53; pp. 428-32; pp. 605-7; pp. 745-8.

30. [1] p. 205.

31. [I] pp. 205-6.

32. Beтt ANY, G. T., Eminent Doctors, Thoir Lives and Their Work, II, 1885, 243.

33. MacCormacx, Sir Williak-Address of Welcome, Centenary R.C.S. Eng., 1900, p. 189.

34. $[27]$

35. S мгтн, T., Topographical and Historical Account of the Parish of St. Marylebone, 1883, p. 231.

36. The Times, 9 August 1884 . Obit.

37. Bellot, HALE-University College, London, 1926, p. 165.

38. Dictionary of National Biography, vol. Lxm.

39. Letters of Erasmus Wilson-R.C.S. Library M.S.S. Box 3 (9).

40. [36]

41. Brit. Med. 7., 1884, II, Editorial, 347.

42. [39]

43. [39]

44. [II] p. 26.

45. WILsON, ERAsmus, History of the Middlesex Hospital during the first hundred years of its existence, 1845, Preface.

46. [1] p. 201.

47. Lancet, 1848 , ii, 723-5.

48. Lancet, 1848, ii, 143 et seq. (vide infra).

49. Lancet, 1848 , ii, 448 .

50. Lancet, 1949, ii, 553 and 644 .

51. Lancet, 1849, i.

52. Lancet, 1849, i, 683 .

53. [33] p. 189 .

54. Lancet, 1884 , ii, 16 August; Obit.

55. [32] p. 245.

56. Lancet, 1884, ii, 692. Review of Inquiry into relative frequency of Diseases of the Skin.

57. [39]

58. Shelley, W. B. and Grissey, J. T., Classics in Clinical Dermatology, Illinois, 1953, p. 120.

59. Annales de Dermatologie et de Syphiligraphie, v, 1884, 502.

60. [59] p. 503.

61. Wilson, Erasmus, 7. Cut. Med., m, 1869, 117 . 


\section{The Life and Works of Sir William Fames Erasmus Wilson}

62. [6r] 1869, II, 198 .

63. [32] p. 245.

64. [39]

65. Lancet, 1873, i, 240.

66. BsSINIR R, Pp. 59,503 .

67. Wilson, ERAsmus, Lectures on Dermatology, 1875, p. 192.

68. Hodosor-Jonss, I. S., St. Bart's. Hosp. F., LIR, 1955, 113.

69. Wilson, ERAsmus, Med. Times and Gazette, $1870,1,118$.

70. Dorlanp, W. A. N., Amorican Illus. Med. Dict., 23rd Ed., 1957.

7I. Stone, Thouas M., Collection of Autographed Letters (R.C.S, Library), pp. 3, 85.

72. Cann, A. Y. Private communication.

73. Royal Med. Benevolent Coll. Rep. Coll. Council Mins, 21.4.1885.

74. Hazel, Williak. Private communication.

75. Lancet, 1879, ii, 704 .

76. University Coll., London, Ann. Rep., I893, p. 13.

77. The Timas, Saturday 9 August 1884 .

78. Vincre T, Haydh's Dict. of Dates.

79. Private communication.

80. Roy. Coll. Surg, Galeudar, Auguati 1956.

81. Vanity Fair, 12 December 1880.

82. The Times, 7 December 1881 .

83. Lancet, 1886, ii, 238.

84. Illus. Lond. Newe, 6 August 1884; Obit.

85. Dictionary of National Biography, vol. LXII.

86. Lancet, $1882, \mathrm{i}, 663$.

87. Lancet, $1882, i, 704$.

88. Lancet, 1882 , ii, 32 .

89. Roy. Coll. Surg. Council Mins., 10 July 1884 .

90. Med. Chir. Trans., LXVIII, 1885, p. 20.

91. [90]

92. The Times, 13 August 1884, $136 b$; $143 a$.

93. [59] p. 501.

\section{ACKNOWLEDGMENTS}

My grateful thanks are due to Mr. J. L. Thornton, Librarian, St, Bartholomew's Hospital Medical College; Mr. W. R. Le Fanu, Librarian of the Royal College of Surgeons; the Wellcome Museum; The Guildhall Library; The Royal College of Music; Miss Fear of the Middlesex Hospital Library; The Times Library; Mr. A. Y. Cann of Epsom College and Mr. D. L. Julier, M.A., without whose help the material for this essay could not have been gathered. Also my thanks are due to the Department of Medical Photography, St. Bartholomew's Hospital for their assistance with the production of photographs, and to Miss A. Lawrence for many hours spent at the typowriter. 